\title{
Validity and reliability of Turkish version of STarT Back Screening Tool
}

\author{
STarT- TR Bel Sağlığı Tarama Ölçeği Türkçe versiyonunun geçerliği ve güvenirliği
}

\author{
(D) Gül Deniz YILMAZ YELVAR, ${ }^{1}$ (D) Murat DALKILINÇ, ${ }^{2}$ (D) Yasemin ÇIRAK, ${ }^{3}$ (D Yasemin PARLAK DEMIR, $^{4}$ \\ (D) Beyza Nur KARADÜZ, ${ }^{5}$ (D) Mümine Merve KOLSUZ ${ }^{6}$
}

\begin{abstract}
Summary
Objectives: The psychosocial factors that may affect the prognosis of patients with low back pain are generally disregarded. The StarT Back Screening Tool can help clinicians to analyze prognostic indicators and the risk associated with outcome by examining physical and psychosocial factors. The aim of this study was to investigate the psychometric properties of the Turkish version of the StarT Back Screening Tool, including cross-cultural adaptation, internal consistency, test-retest reliability, and construct validity. Methods: In this study, 120 patients with non-specific low back pain were included. The Roland Morris Disability Questionnaire, Oswestry Disability Index, Beck Depression Inventory, Tampa Scale for Kinesiophobia, and the StarT Back Screening Tool were administered. One week after the initial testing, the same examiner repeated the tests.

Results: The mean age of the patients who participated in the study was $35.54 \pm 12.45$ years. Cronbach's alpha coefficients in the analysis of scale reliability were 0.747 for the overall scale and 0.738 for the psychosocial subscale. The test-retest reliability of StarT Back Screening Tool (intraclass correlation coefficient: $0.90-0.93$ ) was found to be excellent. Pearson correlation coefficients for the correlations between the overall StarT Back Screening Tool and the other measures were very good $(r=0.678$; $p<0.001)$ for the Roland Morris Disability Questionnaire, good $(r=0.473 ; p<0.001)$ for the Tampa Scale for Kinesiophobia, good $(r=0.541 ; p<0.001)$ for the Oswestry Disability Index, and moderate $(r=0.336 ; p<0.001)$ for the Beck Depression Inventory.

Conclusion: The Turkish version of the StarT Screening Tool for non-specific back pain was determined to be valid and reliable. A good assessment of both physical and psychosocial factors in symptomatic patients can help clinicians make a thorough prognosis.

Keywords: Back screening tool; non-specific low back pain; reliability; Turkish version; validity.
\end{abstract}

\begin{abstract}
Özet
Amaç: Fizyoterapi değerlendirmelerinde genellikle bel ağrıı hastaların prognozunu etkileyebilen psikososyal faktörler gözardı edilmektedir. STarT Bel Sağlığı Tarama Ölçeği (SBST) fiziksel ve psikososyal faktörlerin incelenerek risk seviyeleri konusunda klinisyenlere yardımcı olabilmektedir. Çalışmanın amacı STarT Bel Sağlığı Tarama Ölçeği'nin kültürel adaptasyon, iç tutarlıık, test-tekrar test güvenirliği ve yapı geçerliğini kapsayan psikometrik özelliklerinin incelenmesidir.

Gereç ve Yöntem: Çalışmaya non-spesifik bel ağrısı olan 120 birey dahil edildi. Bireylere Roland Morris Engellilik Anketi, Oswestry Özürlülük İndeksi, Beck Depresyon Envanteri, Tampa Kinezyofobi Ölçeği ve STarT Bel Sağlığı Tarama Ölçeği uygulandı. İlk değerlendirmeden 1 hafta sonra aynı ölçümcü tarafından değerlendirmeler tekrar edildi.

Bulgular: Çalışmaya katılan bireylerin ortalama yaşının 35,54ะ12,45 yıl olduğu görüldü. Tüm ölçeğin güvenirliğinin Cronbach alfa katsayısı tüm ölçek için 0,747, psikososyal alt ölçeğinin ise 0,738'di. STarT Bel Sağlığı Tarama Ölçeği'nin test-tekrar test güvenirliği (ICC: 0,90-0,93) mükemmeldi. STarT Bel Sağlığı Tarama Ölçeği ve diğer ölçümlerin Pearson korelasyon katsayıları: Roland Morris Engellilik Anketi için çok iyi ( $r=0,678, p<0,001)$, Tampa Kinezyofobi Ölçeği'nin iyi $(r=0,473, p<0,001)$, Oswestry Özürlülük İndeksi için iyi $(r=0,541, p<0,001)$ ve Beck Depresyon Envanteri için orta $(r=0,336, p<0,001)$ olarak bulundu.

Sonuç: Start Bel Sağlığı Tarama Ölçeği'nin (STarT-TR) Türkçe versiyonu non-spesifik bel ağrılı bireyler için uygundur ve güvenirliği mükemmeldir. Start Bel Sağlığı Tarama Ölçeği, fiziksel ve psikososyal faktörlerden etkilenen hastaların prognozlarını değerlendirmelerinde klinisyenlere, yardımcı olabilir.
\end{abstract}

Anahtar sözcükler: Bel sağlığı tarama ölçeği; non-spesifik bel ağrısl; güvenirlik; Türkçe versiyon; geçerlik.

'Department of Physiotherapy and Rehabilitation, Cyprus Science University School of Health Science, Northern Cyprus Turkish Republic, Northern Cyprus 2Department of Exercise and Physiotherapy, Presidential Guard, Abu Dhabi, UAE

${ }^{3}$ Department of Physiotherapy and Rehabilitation, İstinte University Faculty of Health Science, Istanbul, Turkey

${ }^{4}$ Independent Researcher in Physiotherapy and Rehabilitation

${ }^{5}$ Department of Physiotherapy and Rehabilitation, Hacettepe University Institute of Health Science, Ankara, Turkey

${ }^{6}$ Department of Language and Speech Therapy, Cumhuriyet University Faculty of Health Science, Sivas, Turkey

Submitted (Başvuru tarihi) 09.12.2018 Accepted after revision (Düzeltme sonrası kabul tarihi) 19.04.2019 Available online date (Online yayımlanma tarihi) 13.06.2019

Correspondence: Dr. Gül Deniz Yılmaz Yelvar. Kıbrıs Ilim Üniversitesi Sağlık Bilimleri Yüksekokulu, Fizyoterapi ve Rehabilitasyon Bölümü, Girne, K.K.T.C.

Phone: +90 - 5336318199 e-mail: guldenizy@yahoo.com

(c) 2019 Turkish Society of Algology 


\section{Introduction}

Low back pain (LBP) is an important musculoskeletal problem that is common in the industrialized world, with a lifetime risk of $84 \%$ and is seen most frequently in the age range of $45-54$ years. ${ }^{[1,2]}$ The prevalence of LBP and levels of pain-associated depression vary between countries and with socio-economic status and disease-coping strategies of patients. It has been reported as $37 \%-51 \%$ and is increasing in those aged over 40 years in Turkey. ${ }^{[3-5]}$

LBP is defined as acute if recovery is within a month, subacute if it lasts 1-3 months and chronic if it continues longer than 3 months. Most patients recover within 6 weeks but in 2\%-7\% of patients symptoms increase. ${ }^{[6]}$ The most important factors in the development of chronic LBP are negative attitudes towards the pain and fear of movement. These conditions significantly affect the psychological status of patients and as a result, the patients feel the pain much more severely and associate the pain with other diseases. At the same time it can lead to difficulty in coping with the disease, lack of confidence and depressive symptoms that affect the prognosis of LBP and increase the cost of medical care. The cognitive-behavioural perspective should therefore be taken into consideration when formulating the appropriate approach to the LBP. ${ }^{[7,8]}$

The identification of possible psychosocial factors that influence the course of the prognosis helps with improved understanding of the patient's results, signs and symptoms and with establishing a more efficient, disease-specific treatment programme. ${ }^{[6]}$ In response to this challenge, the STarT Back Screening Tool (SBST) was developed by Hill et al..$^{[9]}$ to identify subgroups of patients with LBP and to guide initial decision-making. This tool is based on the presence of potentially modifiable physical and psychological indicators for persistent, disabling symptoms, identified through nine questions. It is a simple, selfadministered, valid and reliable questionnaire for screening patients with LBP. It results in a straightforward risk score, which provides an indication of the approach to take. In the large randomized controlled study, Hill et al suggested that physiotherapy and psychotherapy should be recommended for high-risk individuals; physiotherapy should be recommended for moderate-risk individuals and the low-risk individuals should be offered advice and
Assessed for eligibility $(n=137)$

All participants referred to the physiotherapy

clinic were diagnosed by physician

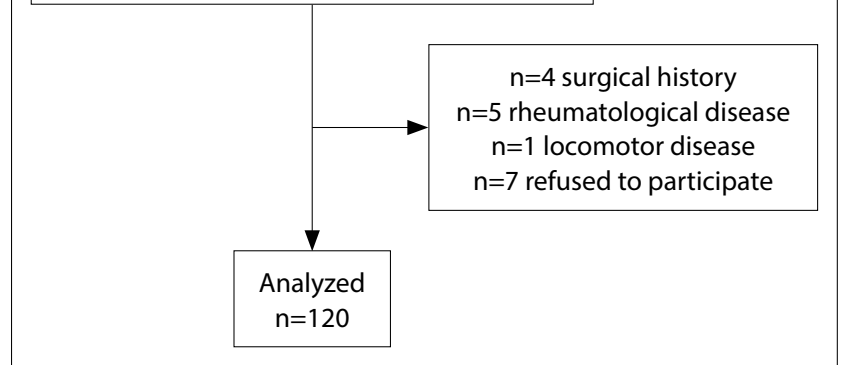

Figure 1. Flowchart for enrollment and testing procedure.

education. This study showed that SBST was a clinical and cost-effectiveness tool. ${ }^{[10]}$

To the best of our knowledge, there is no Turkish screening tool for identifying the possible psychosocial factors that influence the prognosis in patients with LBP. A suitable translation and adaptation of SBST that includes psychosocial factors could therefore enable risk classification for Turkish patients with LBP and help physiotherapists and clinicians in their decision-making. The aim of this study was to investigate the psychometric properties of SBST used to assess the risk status of patients with LBP with regard to cross-cultural adaptation, internal consistency, test-retest reliability and construct validity.

\section{Material and Method}

The study was performed at the University Hospital Department of Physiotherapy and Rehabilitation and included 120 Turkish-speaking participants who were diagnosed by the clinician as non-specific LBP and referred to physiotherapy unit. The patients had locomotor system or rheumatological disease, or a history of fracture or of spinal or pelvic surgery and radiculopathy were excluded.

The study was approved by the University's Human Investigation Committee (2018-08), and all participants read and signed the informed consent form prior to enrolment in the study. Enrolment and a flow chart of the study are shown in Figure 1.

Translation Procedure: We used the guidelines for the cross-cultural adaptation for the translation process. ${ }^{[1]]}$ The linguistic and cross-cultural translation procedure is shown in Table 1. Contact was established via mail with the research group at 
Table 1. Linguistic and cultural translation prosedure

\begin{tabular}{ll} 
Liaison with STarT developers & Contact with the developers \\
Translation & Formation of steering committee \\
Back translation & Translation \\
Synthesis & Back translation from Turkish to English \\
Translation committee & Comparison of translations \\
& Review of translated versions \\
Pilot testing & Reaching consensus and development of pilot version \\
& Testing in clinical setting \\
Final version & Revision of pilot version \\
\hline
\end{tabular}

Keele University that developed STarT and allowed to determine whether there were any attempts in progress to develop a Turkish version of their questionnaire. We established a translation team which consisted of two bilingual physiotherapists, two Turkish-speaking physiotherapists and one bilingual native English-speaking teacher of the English language. The original SBST was independently and separately translated from English to Turkish by the four physiotherapists, after which the four Turkish translations were compared for inconsistencies. A reverse translation into English of the draft Turkish version was then conducted by the fifth member of the team. The team reviewed and compared the original and reversed-translated English versions to detect any errors of interpretation or nuances that may have been missed. The original English, Turkish and reverse-translated English versions and the synthesis of translation differences were discussed by the translation team, who reached a consensus regarding linguistic imprecision and cultural differences. The last stage of the translation process was to test the pre-final version. Ten patients with LBP were administered the translated SBST and asked about item ambiguity and difficulty. All responded that the scale was easy to understand. The final version of SBST was then produced by consensus and this became our final Turkish version of STarT, which we refer to as STarT-TR (Appendix).

SBST includes nine items that referred to leg pain, comorbid pain, difficulties in walking, difficulties in dressing, fear of physical activity, anxiety, pain catastrophizing, depressive mood and the overall impact of pain. Items 1-8 are statements that are answered 'agree' or 'disagree', with positive answers

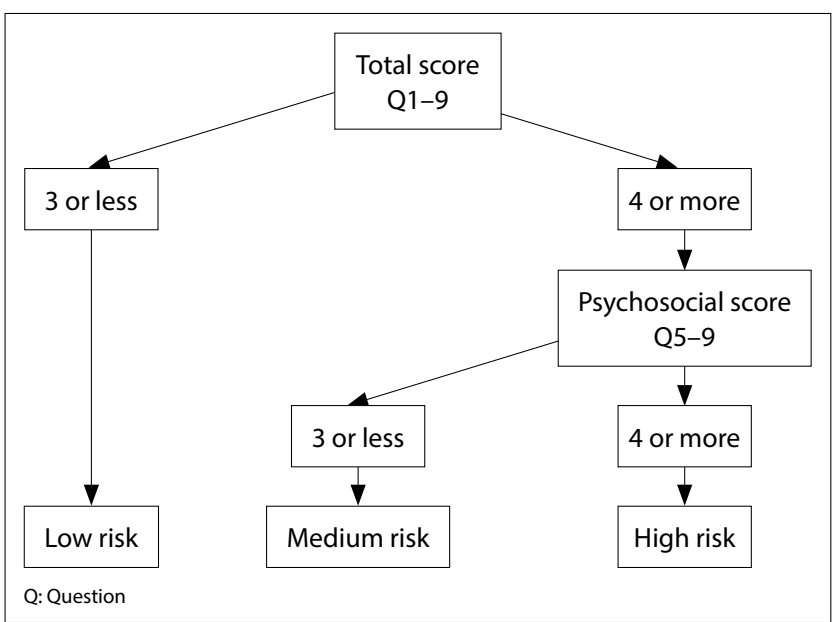

Figure 2. Scoring method of the SBST.

scored as one point and negative as zero points. Item 9 asks how bothersome the pain was over the last 2 weeks and provides a Likert scale from 'Not at all' to 'Extremely', with 'Very much' and 'Extremely' scored as one point and the others as zero. The overall score is simply the sum of all nine item scores. The scores for items 5-9 are also added together to form the psychosocial subscale. The scoring method is shown in Figure $2 .{ }^{[10,12]}$

Roland-Morris Disability Questionnaire (RMDQ) was developed to assess physical disability due to LBP. It results in a score in the range $0-24$, with a score of 14 points or greater indicating risk. ${ }^{[13]}$ We used the items of the Turkish version developed by Küçükdeveci et al. ${ }^{[14]}$

Oswestry Disability Index (ODI) was developed in a specialist referral clinic for patients with chronic LBP. It includes 10 items (pain intensity, personal hygiene, lifting, walking, sitting, standing, sleeping, sexual activity, social activity and travelling) and is scored on a six-point Likert Scale. The scores are summed and re- 
Table 2. Demographic and clinical characteristics of the patients $(n=120)$

\begin{tabular}{|c|c|}
\hline Characteristic & Value \\
\hline \multicolumn{2}{|l|}{ Gender, n (\%) } \\
\hline Male & $46(38.3)$ \\
\hline Female & $74(61.7)$ \\
\hline Age, years, mean (SD) & $35.54(12.45)$ \\
\hline $\mathrm{BMI}, \mathrm{kg} / \mathrm{m}^{2}$, mean (SD) & $24.78(3.43)$ \\
\hline \multicolumn{2}{|l|}{ Duration of the back pain, $n(\%)$} \\
\hline$<1$ month & $48(40)$ \\
\hline $1-3$ month & $38(31.7)$ \\
\hline 4-6 month & $34(28.3)$ \\
\hline \multicolumn{2}{|c|}{ Subgroups as classified on the SBST, $\mathrm{n}(\%)$} \\
\hline High risk & $20(16.7)$ \\
\hline Median risk & $40(33.3)$ \\
\hline Low risk & $60(50)$ \\
\hline \multicolumn{2}{|l|}{ Marital status, n (\%) } \\
\hline Single & $31(25.83)$ \\
\hline Married & $77(64.17)$ \\
\hline Divorced/widowed & $12(10)$ \\
\hline Current smoker, n (\%) & $51(42.5)$ \\
\hline \multicolumn{2}{|l|}{ Educational status, n (\%) } \\
\hline Primary-secondary school & $57(47.5)$ \\
\hline High school & $35(29.16)$ \\
\hline University & $28(23.34)$ \\
\hline \multicolumn{2}{|l|}{ SBST score } \\
\hline Overall (Q1-Q9), mean (SD) & $3.90(2.54)$ \\
\hline Psychosocial subscale (Q5-C & \\
\hline mean (SD) & $7.36(2.62)$ \\
\hline RMDQ score, mean (SD) & $9.89(7.11)$ \\
\hline TSK score, mean (SD) & $40.39(7.11)$ \\
\hline ODI score, mean (SD) & $11.17(6.84)$ \\
\hline BDS score, mean (SD) & $9.18(7.37)$ \\
\hline
\end{tabular}

BMI: Body mass index; SD: Standard deviation; Q: Question; SBST: STarT Back Screening Tool; RMDQ: Roland Morris Disability Questionnaire; TSK: Tampa Scale of Kinesophobia; ODI: Oswestry Disability Index (ODI); BDS: Beck Depression Scale.

calculated as percentages from 0 to 100 , where $100 \%$ refers to the worst possible disability. ${ }^{[15]}$ We used the items of the Turkish version developed by Yakut et al., which has been shown to have good comprehensibility, internal consistency and validity for the assessment of disability in patients with LBP. ${ }^{[16]}$

Beck Depression Inventory (BDI) has 21 items each scored from 0 to 3 according to the intensity of depressive symptoms. ${ }^{[17]}$ We used the items of the Turkish version developed by Hisli. ${ }^{[18]}$
Tampa Scale for Kinesiophobia (TSK) was originally developed by Miller for the assessment of excessive, irrational and debilitating fear of physical movement/(re)injury in patients with back pain but was not published at the time. It was published in 1995 by Vlaeyen et al. ${ }^{[19]}$ We used the items of the Turkish version for which the test-retest reliability has been found to be excellent. ${ }^{[20]}$

\section{Statistical analysis}

Statistical analysis of the data was performed using Statistical Package for the Social Sciences (SPSS) for Windows 16 software. The Kolmogorov-Smirnov test was used to investigate the normality of distribution of the continuous variables. The descriptive statistics were given as the mean \pm standard deviation for the continuous variables and as number of patients and percentage for the categorical variables. We excluded items for homogenity, if skewness exceeded \pm 1 .

Total sample size required to determine a moderete correlation $(r=0.3)$ between SBST scale scores and RMDQ scores for $90 \%$ power was 112 . 120 participants include to study for possible drop outs. ${ }^{[21]}$

Reliability was evaluated by measuring both the internal consistency and test-retest reliability. The appropriate length of the interval depends on the stability of the variables. In this study, 7 days was used as a time interval. Internal consistency was assessed using item-total correlation and Cronbach's alpha. A Cronbach's alpha coefficient $>0.7$ was regarded as satisfactory. Test-retest reliability was determined using the intraclass correlation coefficient (ICC) and Pearson correlation analysis.

Concurrent validity was examined by using Pearson correlations in relation between SBST and RMDQ, TSK, ODI and BDI. Pearson's correlation coefficient values $\geq 0.40$ were considered satisfactory $(r \geq 0.81$ 1.0 , excellent; $0.61-0.80$, very good; $0.41-0.60$, good; $0.21-0.40$, fair and $0.0-0.20$, poor). ${ }^{[22,23]}$

\section{Results}

The mean age of the 120 patients who participated in the study was $35.54 \pm 12.45$ years, ranging from 18 to 50 years, with 74 (61.7\%) female and 46 (38.3\%) male. Table 2 shows the demographic and clinical characteristics of the participants. The mean over- 
Table 3. Reliability of the SBST

\section{Value}

\begin{tabular}{|c|c|}
\hline SBST Overall (Q1-Q9) & 0.747 \\
\hline SBST Psychosocial subscale (Q5-Q9) & 0.738 \\
\hline \multicolumn{2}{|l|}{ Test-retest reliability: ICC } \\
\hline SBST Overall (Q1-Q9) & $0.904(95 \%$ Cl0.762-0.960) \\
\hline SBST Psychosocial subscale (Q5-Q9) & $0.934(95 \% \mathrm{Cl} 0.838-0.973)$ \\
\hline \multicolumn{2}{|l|}{ Test-retest reliability: correlation, $r$} \\
\hline SBST Overall (Q1-Q9) & $0.824(95 \% \mathrm{Cl} 0.757-0.874)^{* *}$ \\
\hline SBST Psychosocial subscale (Q5-Q9) & $0.877(95 \% \mathrm{Cl} 0.828-0.912)^{* *}$ \\
\hline
\end{tabular}

SBST: STarT Back Screening Tool; Q: Question; ICC: Intraclass correlation coefficient; **p $<0.001$.

Table 4. Validity of the SBST

\begin{tabular}{lcc}
\hline Correlation, $\mathbf{r}$ & \\
\hline & SBST overall score & SBST psychosocial subscale \\
\hline RMDQ & $0.678(95 \% \mathrm{Cl} 0.568-0.764)^{* *}$ & $0.585(95 \% \mathrm{Cl} 0.454-0.691)^{* *}$ \\
TSK & $0.473(95 \% \mathrm{Cl} 0.321-0.601)^{* *}$ & $0.480(95 \% \mathrm{Cl} 0.330-0.607)^{* *}$ \\
OID & $0.541(95 \% \mathrm{Cl} 0.401-0.656)^{* *}$ & $0.405(95 \% \mathrm{Cl} 0.244-0.544)^{* *}$ \\
BDS & $0.336(95 \% \mathrm{Cl} 0.167-0.485)^{* *}$ & $0.410(95 \% \mathrm{Cl} 0.250-0.548)^{* *}$ \\
\hline
\end{tabular}

SBST: STarT Back Screening Tool; RMDQ: Roland Morris Disability Questionnaire; TSK: Tampa Scale of Kinesophobia; ODI: Oswestry Disability Index (ODI), BDS: Beck Depression Scale; ${ }^{* *} \mathrm{p}<0.001$.

all SBST score (Items 1-9) was $3.90 \pm 2.54$ and the mean psychosocial subscale score (Items $5-9$ ) was $1.68 \pm 1.79$.

\section{Linguistic and cultural translation}

During the second and third steps of the translation process, for Item 9 the phrase 'Overall, how bothersome...' was translated as 'Overall, how much bothersome.... The translation very close to the original wording was used and difficulties in understanding the meaning of the questions were not found by patients.

\section{Reliability}

Cronbach's alpha coefficients in the analysis of scale reliability were 0.747 for the overall scale (Items 1-9) and 0.738 for the psychosocial subscale (Items 5-9) (Table 3). When the 'alpha if item deleted' values were investigated, all were found to be smaller than the overall alpha values.

The ICC score for test-retest reliability was 0.904 (95\% confidence interval $(\mathrm{Cl}), 0.762-0.960)$ for the overall scale and $0.934(95 \% \mathrm{Cl}, 0.838-0.973)$ for the psychosocial subscale. The Pearson correlation coefficients were $0.824(p<0.05)$ for the overall scale and $0.823(p<0.05)$ for the psychosocial subscale.

\section{Validity}

Pearson correlation coefficients for the correlations between the overall SBST scale and the other measures were as follows: RMDQ very good ( $r=0.678$, $p<0.001)$; TSK good $(r=0.473, p<0.001)$; OID good $(r=0.541, p<0.001)$ and BDI moderate $(r=0.336$, $p<0.001)$. For the psychosocial subscale these values were as follows: RMDQ good $(r=0.585, p<0.001)$; TSK good $(r=0.480, p<0.001)$; OID good $(r=0.405$, $p<0.001)$ and $B D I$ good $(r=0.410, p<0.001)$. These results indicate the concurrent validity of the Turkish version of SBST (Table 4).

\section{Discussion}

This study demonstrated that the Turkish version of SBST (STarT-TR) is a valid and reliable instrument for Turkish-speaking patients with non-specific LBP. SBST that was translated from English to Turkish by 
following international guideline recommendations is provided to literature as a tool with good psychometric properties, easy to use and potentially useful for future epidemiological studies.

The quality of our translation process was good acoording to the Guidelines for the Process of CrossCultural Properties of Self-Report Measures. ${ }^{[1]]}$ Because our translation process met all the 6 criteria for valid translation. The following 6 steps were: (1) initial (forward) translation, (2) synthesis of the translation, (3) back translation, (4) use of an expert committee, (5) testing the prefinal version, and (6) appraisal of the adaptation process. This 6-item tool evaluates the quality of the translation process into a new language or culture through the following 6 steps: (1) initial (forward) translation, (2) synthesis of the translation, (3) back translation, (4) use of an expert committee, (5) testing the prefinal version, and (6) appraisal of the adaptation process. In literature, only 2 versions (Belgian-French and Mandarin) met all the 6 criteria for valid translation according to the guideline. $^{[24]}$

Most functional questionnaires are developed in the English language. For clinical research the source language is of primary importance. Translation difficulties can be encountered in such cultural adaptation studies. In French and Finnish versions, a few minor discrepancies were changed during the translation process. ${ }^{[25,26]}$ At the end of the translation process in our study, there was only one item that needed to be changed in the Turkish version: in Item 9 the phrase 'Overall, how bothersome...' was translated as 'Overall, how much bothersome'. We therefore concluded that this questionnaire was easily understandable by the Turkish population.

SBST is an internationally recognized, valid and reliable tool for screening patients with LBP and has been translated for different cultures, such as Iranian, Spanish, Danish, Brazilian and French. In general, only the translation procedures with cultural adaptation have been reported for these. However, the discriminative validity was tested in the Danish (STarT-dk) and Iranian versions. Although it contains three psychosocial items that were different and have not been validated, STarT-dk was shown to have sufficient patient acceptability in Denmark.
[27] Discriminative validity for the Turkish version should be tested in future studies for development of the psychometric properties. In literature, construct validity was tested in 10 versions by comparing the SBST scores with several constructs of self-reported outcome measures, including pain intensity; functional status; catastrophizing; fear of movement; anxiety and depression; and some quality of life domains. ${ }^{[24]}$ Concurrent validity is considered a subcategory of construct validity and it is another statistical method to test validity, with our study showing the Turkish SBST to be valid for patients speaking the Turkish language. We examined concurrent validity by comparing SBST with RMDQ, TSK, ODI and BDI, which measured similar concepts. Studies translated from the original SBST to different cultures had very different results when examining concurrent validity. The relation between SBST and RMDQ was found to be very good $(r=0.68, p<0.001)$ in this present study. For the French translation, Bruyere $^{[25]}$ observed a high Spearman correlation coefficient of 0.74 between SBST and RMDQ, while the German ${ }^{[28]}$ translation resulted in a moderate Spearman correlation $(r=0.55, p<0.001)$. The Iranian version of SBST was found to be a valid and reliable tool for LBP with lumbar spinal stenosis. ${ }^{[29]}$ They used only the ODI for convergent validity, which showed a strong correlation with the Iranian SBST $(r=0.81, p<0.001)$. In our study, we found a good correlation with ODI $(r=0.541, p<0.001)$. Because of the differences in disease group and risk classification, our study cannot exactly support the Iranian version of SBST. For the German translation, Aebischer et al. observed Spearman coefficient values for the correlation with TSK of 0.40 for the total score and 0.46 for psychosocial subscale. ${ }^{[28]}$ The correlation of the Finnish version of SBST with the BDI gave moderate Spearman coefficient values of 0.38 for the total score and 0.36 for the psychosocial subscale. ${ }^{[26]}$ We found similar results in the present study (total score 0.34 and psychosocial subscale 0.41 ). Also, the majority of versions were validated in physical therapy settings like our study.

Other version studies assessed internal consistency with Cronbach's a like our study. Seven studies assessed internal consistency, Cronbach's a was good $(>0.70)$ except in the Finnish and German versions. ${ }^{[26,28]}$ In literature, in some versions such as Belgian- 
French version the methodologic quality was often found to be poor because Cronbach's a was less than $0.70 .{ }^{[24]}$ But in our study, Cronbach's a was more than 0.70 for SBST Overall and SBST Psychosocial subscale. Also, our sample size recruiting over 100 subjects for testing internal consistency were adequate. So the Turkish version of SBST have a good internal consistency.

In literature, similar to our work, generally the testretest reliability was conducted by using interclass correlation coefficient (ICC). ICC values for SBST ranged from 0.67 (Finnish version) to 0.93 (Mandarin version). ${ }^{[24-30]}$ Smilarly, in our study, the ICC scores for test-retest reliability were excellent for both the overall scale and psychosocial subscale ( 0.90 and 0.93 , respectively).

This study had several strengths. It included patients in the adult population with LBP but no symptoms of osteoarthritis and included a good representation of both sexes. The participants fully responded to all the questions and did not experience difficulty in understanding them. Our study showed that testretest reliability was excellent. However, there were also limitations. We used only concurrent validity for testing validity; discriminative validity should be tested in future studies. Participants between the ages of 18 and 50 years were included in the study, and further assessment of SBST should be performed in an elderly population.

\section{Conclusion}

STarT-TR is available for non-specific LBP and its reliability in this study was perfect. SBST can help clinicians to evaluate the prognosis of patients that are affected by physical and psychosocial factors and it is a straightforward tool for suggesting the most appropriate form of treatment for each patient.

\section{Informed Consent: All participants read and signed the informed consent form prior to enrolment.}

Ethical Approval: The study was approved by the University's Human Investigation Committee (2018-08).

Conflict-of-interest issues regarding the authorship or article: None declared.

Sorces of Support: This study was not funded by any organization.

Peer-rewiew: Externally peer-reviewed.

\section{References}

1. Dreyer SJ and Dreyfuss PH. Low back pain and the zygapophysial (facet) joints. Arch Phys Med Rehabil 1996;77(3):290-300. [CrossRef]

2. Waddell G. Low back pain: a twentieth century health care enigma. Spine (Phila Pa 1976) 1996;21(24):2820-5. [CrossRef]

3. Altinel L, Kose KC, Ergan V, Isik C, Aksoy Y, Ozdemir A, et al. The prevalence of low back pain and risk factors among adult population in Afyon region, Turkey. Acta Orthop Traumatol Turc 2008;42(5):328-33. [CrossRef]

4. Gilgil E, Kacar C, Butun B, Tuncer T, Urhan S, Yildirim C, et al. Prevalence of low back pain in a developing urban setting. Spine (Phila Pa 1976) 2005;30(9):1093-8. [CrossRef]

5. Tucer B, Yalcin BM, Ozturk A, Mazicioglu MM, Yilmaz Y, Kaya M. Risk factors for low back pain and its relation with pain related disability and depression in a Turkish sample. Turk Neurosurg 2009;19(4):327-32.

6. van Tulder $M$, Becker A, Bekkering T, Breen A, del Real MT, Hutchinson $A$, et al. Chapter 3. European guidelines for the management of acute nonspecific low back pain in primary care. Eur Spine J 2006;15(Suppl 2):169-91. [CrossRef]

7. Picavet HS, Vlaeyen JW, and Schouten JS. Pain catastrophizing and kinesiophobia: predictors of chronic low back pain. Am J Epidemiol 2002;156(11):1028-34. [CrossRef]

8. Pincus T, Burton AK, Vogel S, Field AP. A systematic review of psychological factors as predictors of chronicity/disability in prospective cohorts of low back pain. Spine (Phila Pa 1976) 2002;27(5):E109-20. [CrossRef]

9. Hill JC, Dunn KM, Lewis M, Mullis R, Main CJ, Foster NE. A primary care back pain screening tool: identifying patient subgroups for initial treatment. Arthritis Rheum 2008;59(5):632-41. [CrossRef]

10. Hill JC, Whitehurst DG, Lewis M, Bryan S, Dunn KM, Foster $\mathrm{NE}$, et al. Comparison of stratified primary care manage- ment for low back pain with current best practice (STarT Back): a randomized controlled trial. Lancet 2011;378(9802):1560-71. [CrossRef]

11. Beaton DE, Bombardier C, Guillemin F, Ferraz MB. Guidelines for the process of cross-cultural adaptation of self-report measures. Spine (Phila Pa 1976) 2000;25(24):3186-91.

12. Fritz JM, Beneciuk JM, and George SZ. Relationship between categorization with the STarT Back Screening Tool and prognosis for people receiving physical therapy for low back pain. Phys Ther 2011;91(5):722-32. [CrossRef]

13. Roland M, Morris R. A study of the natural history of back pain: 1. Development of a reliable and sensitive measure of disability in low-back pain. Spine 1983;8(2):141-4. [CrossRef]

14. Kucukdeveci AA, Tennant A, Elhan AH, Niyazoglu H. Validation of the Turkish version of the Roland-Morris Disability Questionnaire for use in low back pain. Spine (Phila Pa 1976) 2001;26(24):2738-43. [CrossRef]

15. Fairbank JC, Couper J, Davies JB, O'Brien JP. The Oswestry low back pain disability questionnaire. Physiotherapy 1980;66(8):271-3.

16. Yakut E, Duger T, Oksuz C, Yorukan S, Ureten K, Turan D, et al. Validation of the Turkish version of the Oswestry Disabil- 
ity Index for patients with low back pain. Spine (Phila Pa 1976) 2004;29(5):581-5. [CrossRef]

17. Beck AT, Steer RA, Carbin MG. Psychometric properties of the Beck Depression Inventory: Twenty-five years of evaluation. Clin Psych Rev 1988;8(1):77-100. [CrossRef]

18. Hisli N. Beck Depresyon Envanterinin geçerliği üzerine bir çalışma. Psikoloji Dergisi 1998;22:118-27.

19. Vlaeyen JW, Kole-Snijders AM, Boeren RG, and van Eek $\mathrm{H}$. Fear of movement/(re)injury in chronic low back pain and its relation to behavioral performance. Pain 1995;62(3):363-72. [CrossRef]

20. Tunca Yimaz O, Yakut Y, Uygur F, Uluğ N. Tampa Kinezyofobi Ölçeği'nin Türkçe versiyonu ve test-tekrar test güvenirliği. Fizyoter Rehabil 2011;22(1):44-9.

21. Hulley SB, Cummings SR, Browner WS, Grady D, Newman TB. Designing clinical research: an epidemiologic approach. 4th ed. Philadelphia, PA: Lippincott Williams\&Wilkins; 2013.

22. Feise RJ, Michael Menke J. Functional rating index: a new valid and reliable instrument to measure the magnitude of clinical change in spinal conditions. Spine (Phila Pa 1976) 2001;26(1):78-86. [CrossRef]

23. Kirkwood BR, JAC S. Essential medical statistics. Massachusetts, USA: Oxford Blackwell Publishing Ltd; 2004.

24. Al Zoubi FM, Eilayyan O, Mayo NE, Bussières AE. Evaluation of Cross-Cultural Adaptation and Measurement Properties of STarT Back Screening Tool: A Systematic Review. J Manipulative Physiol Ther 2017;40(8):558-72. [CrossRef]

25. Bruyere O, Demoulin M, Brereton C, Humblet F, Flynn D, Hill JC. Translation validation of a new back pain screening questionnaire (the STarT Back Screening Tool) in French. Arch Public Health 2012;70(1):12. [CrossRef]

26. Piironen S, Paananen $M$, Haapea $M$, Hupli M, Zitting $P$, Ryynanen $\mathrm{K}$, et al. Transcultural adaption and psychometric properties of the STarT Back Screening Tool among Finnish low back pain patients. Eur Spine J 2016;25(1):28795. [CrossRef]

27. Morso L, Albert $H$, Kent $P$, Manniche $C$, Hill J. Translation and discriminative validation of the STarT Back Screening Tool into Danish. Eur Spine J 2011;20(12):2166-73. [CrossRef]

28. Aebischer B, Hill JC, Hilfiker R, Karstens S. German Translation and Cross-Cultural Adaptation of the STarT Back Screening Tool. PLoS One 2015;10:e0132068. [CrossRef]

29. Azimi P, Shahzadi S, Azhari S, and Montazeri A. A validation study of the Iranian version of STarT Back Screening Tool (SBST) in lumbar central canal stenosis patients. J Orthop Sci 2014;19(2):213-7. [CrossRef]

30. Pilz B, Vasconcelos RA, Marcondes FB, Lodovichi SS, Mello W, Grossi DB. The Brazilian version of STarT Back Screening Tool - translation, cross-cultural adaptation and reliability. Braz J Phys Ther 2014;18(5):453-61. [CrossRef] 


\section{Appendix}

\section{STaRT-TR BEL SAĞLIĞI TARAMA FORMU}

Hastanın Adı Soyadi:

Tarih:

Son 2 haftayı düşünerek aşağıdaki sorularda uygun seçeneği işaretleyin:

\begin{tabular}{|c|c|c|}
\hline & $\begin{array}{c}\text { Katılıyorum } \\
1\end{array}$ & $\begin{array}{c}\text { Katılmıyorum } \\
\text { 0 }\end{array}$ \\
\hline $\begin{array}{l}1 \text { Bel ağrım geçen } 2 \text { hafta içinde } \text { zaman zaman } \\
\text { bacak(larıma) doğru yayıldı }\end{array}$ & & \\
\hline $\begin{array}{l}2 \text { Geçen } 2 \text { hafta içinde zaman zaman omuz ve boynumda } \\
\text { ağrılarım oldu }\end{array}$ & & \\
\hline $\begin{array}{l}3 \text { Belimin ağrısı nedeniyle sadece } \text { kısa mesafeler } \\
\text { yürüdüm. }\end{array}$ & & \\
\hline $\begin{array}{l}4 \text { Son } 2 \text { hafta içinde, bel ağrısı nedeniyle normalden daha } \\
\text { yavaș giyindim }\end{array}$ & & \\
\hline $\begin{array}{l}5 \text { Benim durumumdaki birisi için fiziksel olarak aktif } \\
\text { olmak gerçekten güvenli değil }\end{array}$ & & \\
\hline $\begin{array}{l}6 \text { Çoğu zaman zihnimden endişe verici düşünceler } \\
\text { geçmektedir }\end{array}$ & & \\
\hline $\begin{array}{l}7 \text { Bel ağrımın çok kötü olduğunu ve asla daha iyi } \\
\text { olmayacağını hissediyorum }\end{array}$ & & \\
\hline $\begin{array}{l}8 \text { Genel olarak, daha önce keyif aldığım şeylerden keyif } \\
\text { almadım }\end{array}$ & & \\
\hline
\end{tabular}

9. Genel olarak, bel ağrınız son 2 hafta içinde ne kadar en sıkıcı olmuştur?

$\begin{array}{ccccc}\text { Hiç } & \text { Biraz } & \text { Orta Derecede } & \text { Çok } & \text { Aşırı } \\ 0 & 0 & 0 & 1 & 1 \\ \square & \square & \square & \square & \square\end{array}$

Toplam skor (tüm 9):

Alt skor (S5-9): 